cover crops, green manures, and crop rotations, and discuss soil management and soil fertility. Section Two deals with pest management, including Integrated Pest Management (IPM) techniques, control strategies for some of the major pest problems that growers face, including insects, mites and mammals, weeds, and plant pathogens. Section Three contains four chapters on crop production: vegetables and herbs, small fruits, greenhouse crops, and tree fruits. The two chapters in Section Four deal with livestock and dairy management; one is on production, the other comprises case studies from six organic animal producers. Section Five contains three chapters on management and marketing, including growers' diverse opinions about charging price premiums for organically grown food, while Section Six contains two chapters on integrated farming sys- tems and the transition from conventional to organic farming.

In addition to the information assembled from farmer interviews and researcher comments, the authors have incorporated a great deal of information from other sources. For example, Chapter Four on soil fertility from amendments includes a table on characteristics of organic fertilizers adapted from a chart compiled by Necessary Trading Co.

The book concludes with several appendices: a glossary, although some technical terms are not included (greensand, for instance); profiles describing the farmer and farm history for most of the farmers who contributed to the discussions; a list of northeast organic growers associations and certification programs; a resource directory; a list of northeast regional Cooperative Extension and IPM coordinators; a list of reviewers; and a bibliography for additional information.

Growers comments included in this book are based on their field observations and experiences with growing conditions determined by the particulars of their own farms. Readers hoping to use this book as an authoritative field guide should be aware that the reports of field phenomena are not derived from monitored field studies. Nonetheless, readers will find that the variety of opinions and observations offered in this book make stimulating reading.

Wendy Mechaber, Research Associate, Department of Biology and School of Nutrition, Tufts University, Medford, MA 02155.

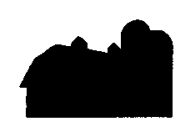

\title{
UPCOMING EVENTS
}

January 10-12, 1995, the 1995 California Chapter, American Society of Agronomy, Annual Meeting will be held in Visalia, CA; contact Shannon Mueller, Fresno County Farm Advisor; (209)488-3285.

January 13-15, 1995, the Southern Sustainable Agriculture Working Group will host its 4th Annual Conference and Trade Show in Gulf Shores, AL; contact Keith Richards, PO Box 324, Elkins, AR 72727, (501)292-3714.

January 14, 1995, Environmental Justice, Population, and the New Majority of Color will be held al Holman United Methodist Church, Los Angeles, CA; contact EDGE: The Alliance of Ethnic and Environmental Organizations, 300 Broadway, \#39, San Francisco, CA 94133; (415)4216891.

January 14, 1995, Gifts of Good Soil, the 6th Annual Southern Plains Conference, will be held in Amarillo, TX; contact Darryl Birkenfeld, Southern Plains Conference, PO Box 5644, Amarillo, TX 79117; (806)364-1551.
January 16-18, 1995, Achieving Global Human Security, the 1995 International Development Conference, will be held in Washington, D.C.; contact Kathy Morrell \& Associates, Inc., PO Box 11276 , Alexandria, VA 22312; (703)642-3628.

January 23-25, 1995, the 1995 Conference on Sustainable Agriculture, sponsored by The Council for Agricultural and Science Technology, will be held in Washington, D.C.; contact Jon Hiler, Membership \& Community Services, ASAE, 2950 Niles Road, St. Joseph, MI 49085-9659; (616)428-6327; e-mail hiler@asae.org or hilerj@aol.com

January 24-25, 1995, the 16th Annual Eastern Iowa Conservation Tillage Show, sponsored by the USDA Soil Conservation Service, will be held in Cedar Rapids, IA; contact C.W. Lawrence, Jones County Soil Conservationist, 405 East Main St. Anamosa, IA 52205; (319)462-3196.

January 25-28, 1995, Seeds of Sustainability-Planting Our Future, the 15th Annual Ecological Farming Conference, will be held at the Asilomar Conference Center, Pacific Grove, CA; contact Committee for Sustainable Agriculture, PO Box 838, San Martin, CA 95046; (408)778-7366.

January 27-29, 1995, the 14th winter conference of the Northern Plains Sustainable Agriculture Society will be held in Aberdeen, S.D.; contact the Society, HC 5 Box 104, Langdon, ND 58249; (710)2562424.

January 27-28, 1995, Organic Agriculture: Growing the Network, the 14th annual Organic Agriculture Conference, will be held at the University of Guelph, Ontario, Canada; contact Hugh Martin, Ontario Ministry of Agriculture, Food \& Rural Affairs, (519)631-4700, or Tomas Nimmo, Canadian Organic Growers, (705)444-0923.

February 5-9, 1995, Jazzing Up Conservation, the National Association of Conservation Districts 1995 Annual Meeting, will be held in New Orleans, LA; contact NACD Service Center, 1-800-8255547. 
February 7-9, 1995, the New York State Direct Marketing Conference will be held in Batavia, N.Y.; contact Ken Silsby, Conference Chairman, (716)433-2651.

February 24-25, 1995, the Pacific Northwest Farm Direct Marketing Conference will be held in British Columbia, Canada; pre-conference tours will be held February 22-23; a post-conference tour will be held February 26; contact Pacific Northwest Farm Direct Marketing Association, PO Box 722, Prosser, WA 99350-0722; (509)786-1000.

February 28-March 2, 1995, the 4th International IFOAM Conference on Trade in Organic Products will be held in Wiesbaden, Germany; March 3-5, 1995, $B I O F A C H$ ' 95 , an IFOAM Trade Fair, will be held at the same location; contact IFOAM Trade Conference '95, Sunder \&
Rottner, Von-Vollmar-Str. 4, D-91154 Roth, Germany; phone, 9171-4011.

February 28-March 3, 1995, Carrying the Torch for Erosion Control-An Olympic Task, the 26th annual International Erosion Control Association Conference and Trade Exposition, will be held in Atlanta, GA; contact IECA, PO Box 4904, Steamboat Springs, CO 80477-4904; (303)8793010 .

March 4-5, 1995, the 13th annual conference of the Northeast Organic Farming Association of New York will be held at Tompkins/Cortland Community College, Dryden, N.Y; contact Ammie Chickering, NOFA-NY, PO Box 21, South Butler, N.Y. 13154-0021; (315)365-2299.

April 27-30, 1995, an International Conference on Environmental Ethics and the Global Marketplace will be held in
Athens, GA; contact Richard C. Field, Georgia Center for Continuing Education, University of Georgia, Athens, GA 306023603; (706)542-3063.

May 8-10, 1995, Planning for a Sustainable Future: The Case of the North American Great Plains will be held in Lincoln, NE; contact Dr. Donald A. Wilhite, Director, International Drought Information Center, PO Box 830728, University of Nebraska, Lincoln, NE 68583-0728;(402)472-6707;e-mail agme002@unlvm.unl.edu

June 10-13, 1995, Environmental Challenges: The Next 20 Years will be held in Washington, D.C.; contact the National Association of Environmental Professionals, 5165 MacArthur Blvd., NW, Washington, D.C. 20016-3315; (202)966-1500.

\section{EPA Will Phase Out Uses of 36 Pesticides under Lawsuit Settlement}

The U.S. Environmental Protection Agency (EPA) will begin phasing out uses of 36 cancer-causing pesticides as a result of an out-of-court settlement of a lawsuit that charged the agency had violated the Delaney Clause by allowing residues of carcinogenic pesticides in processed foods. The Delaney Clause prohibits the presence in processed foods of even minute amounts of cancer-causing pesticide residues. The settlement also calls for the EPA to review within five years an additional 49 cancer-causing pesticides to determine whether they should also be eliminated from certain uses. According to the Natural Resources Defense Council, the lead plaintiff of the lawsuit, the 36 pesticides and their uses include: alachlor, used on soybeans and peanuts; benomyl, a fungicide used on apples, citrus, grapes, rice, and tomatoes; captan, used on grapes, plums, and tomatoes; mancozeb, used on cereal grains and grapes; and dicofol, used on fruits and tomatoes.

"The most pronounced effect of the settlement will be to increase the pressure on Congress to enact a far-reaching new law governing pesticides," said an article in The New York Times. "Such an overhaul could supersede the EPA settlement." The Clinton Administration had proposed a new bill creating a less rigid standard for pesticides used in processed food, but neither that bill nor any other pesticide reform bills introduced in Congress was passed during the past session. Those proposals are expected to be reintroduced when the next session of Congress starts this year.

\section{Concerned about Pesticides, Shoppers Seek Organic Foods, Survey Finds}

In response to concern about the use of pesticides and agricultural chemicals, and the performance of the federal government in protecting consumers from those chemicals, shoppers are actively seeking out organically grown produce, according to a recent survey of food shoppers' attitudes about organic produce. The survey of 1,000 food shoppers, commissioned by Rodale Press, Inc., found that nearly one out of every three has changed his or her eating habits $(30 \%)$ or sought out organically grown produce (32\%) in the past year due to reports about pesticide and chemical use.

The majority (72\%) of shoppers who changed their eating habits for this reason specifically sought out organically grown fruits and vegetables, according to the survey. Of all the shoppers polled, $64 \%$ had eaten organic fruits and vegetables; of those, $59 \%$ said the most important reason for buying organic produce was long-term health benefits, and $21 \%$ cited the nutritional value of the produce. Of shoppers who have never eaten organic produce, $77 \%$ said they would buy it if it cost the same as non-organic fruits and vegetables. The majority (68\%) of shoppers surveyed think the federal government is doing a fair or poor job of protecting consumers from potentially harmful chemicals and pesticides in fruits and vegetables. For more information about the survey, contact Robert Martin, Rodale Press, Inc., 33 E. Minor St., Emmaus, PA 18098; (610)967-7588. 